\title{
Medical History Data Collection Date Time
}

National Cancer Institute

\section{Source}

National Cancer Institute. Medical History Data Collection Date Time. NCI Thesaurus.

Code C83328.

The date and time a medical history was collected. 